ANNA DATKO

\title{
ZA DYPLOMEM? MIGRACJE MŁODYCH POLAKÓW DO MIAST AKADEMICKICH
}

ABSTRACT. Datko Anna, Za dyplomem? Migracje młodych Polaków do miast akademickich [Chasing a diploma? Migration to Polish academic cities] edited by J. Kubera, Ł. Skoczylas - „Człowiek i Społeczeństwo", vol. XXXVII, Poznań 2014, pp. 41-51, Adam Mickiewicz University Press. ISBN 978-83-232-2764-9. ISSN 0239-3271.

The 21st century is an age of mobility. Young Poles have also adapted to this trend - they migrate both abroad and within the confines of their own country. In the paper the author presents the migration to Polish academic cities, to which people arrive because of beginning their studies. But they do not only want to graduate from a university. Moving from their hometown entails too some bigger aims, such as launching a successful professional career, or staying and living in a big city and in consequence being a member of the metropolitan middle class.

Academic education is considered due to its usefulness in gaining these aims (through the instrumental role of higher education) - and studies are more and more only a legitimization of a permanent migration to a metropolis.

Anna Datko, Uniwersytet im. Adama Mickiewicza w Poznaniu, Instytut Socjologii, ul. Szamarzewskiego 89c, 60-568 Poznań, Poland.

„O kierunkach migracji przesądza nie tyle obecny stan rzeczy w miejscu przebywania, ile perspektywy i oczekiwania. Oczekiwania te są zawsze w jakiejś mierze funkcją tego stanu, ale są również wypadkową wyobrażeń co do sytuacji w przyszłości w dwu różnych punktach na mapie. Zawsze nie tylko skądś się wyjeżdża, ale też dokądś jedzie" (Kołodko 2008: 369).

Przytoczone na wstępie słowa Grzegorza W. Kołodki dotyczą co prawda migracji zagranicznych, zewnętrznych, w toku których jednostki zmieniają kraj urodzenia, pochodzenia czy zamieszkiwania na inny, będący docelowym miejscem krótszego lub dłuższego, ale zawsze w miarę stałego osiedlenia, lecz śmiało można je odnieść również do przemieszczeń ludności w ramach jednego państwa, czyli migracji wewnętrznych ${ }^{1}$. Niniejszy tekst,

${ }^{1}$ Migracje wewnętrzne to przemieszczenia ludności w ramach granic państwowych. Dotyczą zmiany gminy zamieszkania, zarówno w sensie geograficznym (wewnątrzwojewódzkie, 
będący próbą zasygnalizowania pewnych tendencji i refleksją nad trendami w działaniach młodych Polaków, poświęcam właśnie migracjom wewnętrznym, w szczególności jednemu typowi takich przemieszczeń, a mianowicie zmianie miejsca stałego pobytu związanej z kształceniem na poziomie wyższym. Mam tu na myśli przede wszystkim migrację $\mathrm{z}$ dotychczasowego miejsca zamieszkania, najczęściej tożsamego z domem rodzinnym, do miast akademickich. Jakie oczekiwania, aspiracje i motywacje stoją za decyzją o przeprowadzce? Czy główny i naturalnie nasuwający się powód migracji, czyli podjęcie studiów na wyższej uczelni i uzyskanie formalnego wykształcenia wyższego, faktycznie jest podstawową determinantą przyjazdów do centrów akademickich? Przemiany instytucjonalne, ideologiczne i kulturowe, jakie zachodzą w systemie kształcenia na studiach wyższych, każą zastanowić się również, gdzie w hierarchii wartości i motywacji do przybycia do miasta uniwersyteckiego plasuje się dążenie do zdobycia wykształcenia (zob. np.: Bromberek 1988; Jankowska, Krasoń 2009; Nowak 1991).

Współcześnie migracje wewnętrzne stosunkowo rzadko spotykają się $\mathrm{z}$ zainteresowaniem badaczy życia społecznego ${ }^{2}$. Jest to wynik przede wszystkim ogromnego wzrostu ilościowego migracji zagranicznych, związanego na naszym kontynencie z procesami integracji europejskiej, stopniowym zanikaniem granic państwowych, coraz szybszymi, łatwiejszymi możliwościami fizycznego przemieszczania się na duże odległości, a także przenikaniem wzorców kulturowych i cywilizacyjnych. Interesującym aspektem migracji zewnętrznych jest właśnie ten styk różnych kultur oraz sposobów i stylów życia, pociągający za sobą rozmaite strategie adaptacyjne i asymilacyjne zarówno imigrantów, jak i stron przyjmujących. Migracja zewnętrzna oznacza pozostawienie ojczyzny, często rodziny, kręgów przyjacielskich, konieczność przystosowania do odmiennych od własnych zwyczajów i norm, posługiwania się obcym językiem, wykonywania, przynajmniej na początku, wcale nie dobrze płatnej pracy (poniżej kwalifikacji lub diametralnie się od nich różniącej), funkcjonowanie w złych warunkach materialnych, a nierzadko i życie ze swoistym piętnem imigranta. Problemy te, a także wiele innych, implikowanych przemieszczeniami poza granice własnego państwa, sprawia, że migracje zewnętrzne, jako zagadnienie bardzo złożone, są przez to ciekawsze poznawczo (zob. np.: Iglicka 2010; Kaczmar-

międzywojewódzkie etc.), jak i administracyjnym (ze wsi do miast i na odwrót, między miastami etc.). Migracjami określa się pobyty w danym miejscu trwające dłużej niż dwa miesiące, nie bierze się zaś pod uwagę ruchów wahadłowych. Definicje, typologia i charakterystyka zob. Migracje wewnętrzne... 2003.

2 Badania nad migracjami prowadzi od 1993 roku Ośrodek Badań nad Migracjami Uniwersytetu Warszawskiego. 
czyk 2012; Okólski 2011). Migracja wewnątrzpaństwowa, zwłaszcza w tak zdawałoby się jednorodnym kulturowo kraju jak Polska, wiąże się z na pozór mniejszymi kosztami i konsekwencjami. Choć doświadczenia te są naturalnie jakościowo różne, to jednak migracja wewnętrzna do ośrodków miejskich również jest swego rodzaju zetknięciem z inną kulturą (Łukasiuk 2007) kulturą metropolitalną, której głównymi twórcami są aktorzy sektora finansowego, szeroko pojętego otoczenia biznesu, mediów, wyspecjalizowanej konsumpcji i instytucje kulturalne o międzynarodowej randze (Jałowiecki, Szczepański 2009: 213) ${ }^{3}$.

Trzeba dodać, że w obecnych warunkach nie tylko zainteresowanie czysto eksploracyjne przyciąga uwagę badaczy do wyjazdów na stałe. Po wstąpieniu Polski do Unii Europejskiej (w 2004 roku) i otwarciu dla Polaków rynków pracy w innych krajach wspólnoty emigracja zarobkowa i znaczący odpływ z kraju potencjalnej siły roboczej i nabywczej zyskały na znaczeniu jako problemy stricte polityczne o negatywnych konsekwencjach (w tym m.in. stale zmniejszający się przyrost naturalny, którego jedną z przyczyn jest masowa emigracja), jakim należy przeciwdziałać, stosując odpowiednie środki zaradcze. Emigracja powodowana jest w większości względami materialnymi - bezrobociem, brakiem perspektyw na znalezienie satysfakcjonującej finansowo, a często i jakiejkolwiek pracy, niemożnością znalezienia zatrudnienia zgodnego z indywidualnymi kwalifikacjami, przygotowaniem zawodowym czy predyspozycjami. Politycy i decydenci pochylają się zatem szczególnie nad możliwościami przekształceń w ramach rynku pracy. Polem zmian jest jednak nie sam rynek pracy, kształtujący się niejako samoistnie, w duchu ideologii neoliberalnej i bez ingerencji państwowej, ale uważany za kuźnię kadr dla gospodarki system szkolnictwa wyższego (por. np.: Potulicka, Rutkowiak 2010; Pachociński 2004). Motorami napędowymi tego systemu w dalszym ciągu pozostają uczelnie wyższe usytuowane we wspomnianych wcześniej centrach akademickich, stanowiące miejsca docelowe większości migracji wewnętrznych. Mamy tu do czynienia ze sprzężeniem zwrotnym, gdyż środowisko akademickie ma ze swej strony bardzo duży potencjał miastotwórczy. Jak twierdzi Marek Ratajczak, koordynator zespołu tworzącego strategię rozwoju naukowego i akademickiego miasta Poznania, "studenci kształcący się $\mathrm{w}$ poznańskich uczelniach to istotny czynnik miastotwórczy i dochodotwórczy. Nawet jeśli przeciętny student nie dysponuje znacznymi środkami finansowymi, to i tak korzysta z punktów gastrono-

\footnotetext{
3 Proces metropolizacji obejmuje nie tylko rozwój miast $\mathrm{w}$ sensie urbanistycznym, ale też zmianę całej tkanki społecznej i miejskiej zarówno metropolii, jak i aglomeracji miejskich oraz regionów od niej zależnych, co oznacza zmianę społeczeństwa (Jałowiecki, Szczepański 2009: 213).
} 
micznych, placówek handlowych, wydatkuje swoje fundusze na najem mieszkań i kulturę"4.

Ośrodkami miejskimi o największej mocy przyciągania są: Warszawa (niekwestionowany lider i jedyne polskie miasto, które można uznać za metropolię na miarę europejską), Kraków, Łódź, Wrocław, Poznań oraz Gdańsk. Dzieje się tak, choć boom edukacyjny lat dziewięćdziesiątych XX wieku spowodował rozwój prywatnego sektora szkolnictwa wyższego, a co za tym idzie, powstawanie placówek uczelnianych również $\mathrm{w}$ mniejszych ośrodkach miejskich, otwieranie w nich filii wielkomiejskich szkół wyższych oraz powołanie i funkcjonowanie uniwersytetów we wszystkich stolicach województw (Bajerski 2009; Drozdowicz, Iwaszkiewicz (red.) 2008). Dają one oczywiście możliwość studiowania i uzyskania tytułu licencjata czy magistra, lecz nadal pozostają ośrodkami peryferyjnymi ${ }^{5}$, które poza zajęciami dydaktycznymi niewiele oferują $\mathrm{w}$ sferach ważnych dla jednostkowego rozwoju (Herbst 2012).

Przybywanie rzesz studentów do dużych polskich miast jest zjawiskiem obserwowanym masowo od czasów powojennych, kiedy to szkolnictwo wyższe zaczęło podlegać procesom upowszechnienia, i od tego czasu jest fenomenem niesłabnącym ${ }^{6}$. Na przestrzeni lat - od okresu PRL, przez czas transformacji, do chwili obecnej - zmieniały się jednak motywy oraz aspiracje młodzieży. Charakter uzasadnień owych napływów także nie jest dziś

4 Wypowiedź M. Ratajczaka: http://www.ue.poznan.pl/uczelnia/informacje-prasowe524/ [dostęp: 19.04.2013]. Co ciekawe, właśnie obecna sytuacja w Poznaniu może być przykładem wagi wzajemnych relacji miasta i instytucji akademickiej. Poznański Uniwersytet im. Adama Mickiewicza przenosi bowiem lokalizację wielu wydziałów i placówek dydaktycznych poza obręb ścisłego centrum. Rozbudowa kampusu Morasko ma spowodować, zdaniem niektórych badaczy i publicystów (dyskusja na ten temat toczyła się i toczy na łamach "Gazety Wyborczej Poznań"), odpływ studentów i pracowników naukowych ze śródmieścia, co może doprowadzić z jednej strony do izolacji przedstawicieli środowiska uczelnianego od udogodnień i infrastruktury centrum (instytucji naukowych i kulturalnych, lokali rozrywkowych i gastronomicznych etc.), a z drugiej - pogłębi jego degradację. Jednakże władze administracyjne przekonują, że nowoczesny kampus oddalony od miasta jest najlepszym rozwiązaniem modernizacyjnym dla uczelni i zwiększa komfort studiowania oraz pracy naukowej, co z kolei podwyższa ich jakość i pomaga tworzyć ośrodek akademicki na wzór zachodni (polemika redaktora „GW" A. Kompowskiego z rzeczniczką UAM D. Narożną).

Tę swoistą migrację uniwersytetu można uznać za wpisującą się $\mathrm{w}$ trend traktowania uczelni wyższych jak przedsiębiorstw i zarządzanych na zasadach panujących $\mathrm{w}$ ramach gospodarki rynkowej. Wyprowadzka poza centrum Poznania jest bowiem dla UAM opłacalna $\mathrm{w}$ sensie finansowym, a to przecież ten argument w kulturze kapitalizmu jest decydujący.

5 Magdalena Łukasiuk wysnuwa ze swych badań dotyczących współczesnych migracji ludzi z wyższym wykształceniem do Warszawy wniosek, że każde miasto oprócz stołecznego jest w świadomości społecznej prowincjonalnym (Łukasiuk 2007: 188-192).

${ }^{6} \mathrm{O}$ postępującej egalitaryzacji kształcenia akademickiego w Polsce po II wojnie światowej zob. np. Micińska 2008. 
taki sam jak niegdyś. Uzyskanie wykształcenia, usamodzielnienie się, „wyrwanie się" z domu, zmiana środowiska zawsze były powodami, dla których decydowano się na studia $\mathrm{w}$ takim czy innym ośrodku akademickim. Jednakże obecnie młodzi ludzie mają dużo bardziej sprecyzowane oczekiwania wobec czasu studiów i swego przyjazdu do metropolii. Studia akademickie i zdobycie wyższego wykształcenia można uznać za legitymizację migracji, lecz nie jej podstawowy cel. Kandydaci na studia nie rozpatrują przyjazdu do miasta akademickiego w kategorii pobytu czasowego; planem jest pozostanie $\mathrm{w}$ mieście po zakończeniu tego etapu edukacjī. Powrót do rodzinnej miejscowości nie jest rozpatrywany jako możliwa ścieżka życiowa, ponieważ oznacza współcześnie swego rodzaju porażkę - ten, kto wraca, nie potrafił się odnaleźć, nie dał sobie rady, nie przystawał do wiodącej prym kultury metropolitalnej, nie był wystarczająco dobry, by odnieść sukces na wymagającym, ale jakże atrakcyjnym rynku pracy. Samo ukończenie studiów nie jest uznawane za sukces - $w$ dobie masowości kształcenia akademickiego ${ }^{8}$ jest to kolejny naturalny etap na drodze indywidualnego rozwoju. Sukcesem jest natomiast rozpoczęcie kariery zawodowej, choć w polskich realiach, a ogólniej - w realiach ogólnoświatowego kryzysu gospodarczego, którego skutki odczuwamy również $\mathrm{w}$ Polsce, miarą powodzenia staje się dzisiaj sam fakt zatrudnienia i możliwość wykonywania jakiejkolwiek pracy zarobkowej9. W okresie PRL, gdy problem bezrobocia praktycznie nie istniał, powrót do rodzimej miejscowości, a już na pewno do innego niż akademickie miasta, nie był postrzegany aż tak negatywnie. Ideologia socjalistyczna nakazywała wręcz przekazywanie nowego typu wiedzy i stylu życia, jakie wykształcały się w absolwentach szkół wyższych, jak najszerszym kręgom. Powodem do wstydu był natomiast powrót z zagranicy, w szczególności na wieś, zwłaszcza gdy reemigrant nie przywoził ze sobą środków materialnych, za co spotykała go krytyka i nieprzychylność środowiska lokalnego (Sadowski 1994: 30).

\footnotetext{
7 Badania na ten temat przeprowadzano np. na Podkarpaciu w 2010 roku. Studenci z badanego regionu pytani o plany pozostania $\mathrm{w}$ miejscu studiowania po zakończeniu edukacji akademickiej w większości wyrażają chęć podjęcia takiego kroku: na stałe lub przez jakiś czas chce zamieszkać w ośrodku akademickim 50,9\% respondentów, 28,1\% jeszcze o tym nie zdecydowało. Przyszły powrót zadeklarował jedynie co piąty badany (Bieńkowska, Ulasiński, Szymańska (red.) 2010).

8 Współczynnik skolaryzacji brutto na poziomie wyższym wyniósł w roku akademickim 2010/2011 53,8\% (za: Szkoty wyższe... 2011).

9 Bezrobocie rejestrowane w Polsce wynosiło w lutym 2013 roku 14,4\% (było o punkt procentowy wyższe niż w lutym poprzedniego roku). Jeszcze wyższa jest stopa bezrobocia wśród ludzi młodych; w I kwartale 2012 roku w przedziale od 20 do 24 lat wynosiła 20,9\%, zaś w przedziale wiekowym od 25 do 34 lat $33,2 \%$. Warto zaznaczyć, że wyższe wykształcenie nadal jest ochroną przed bezrobociem - w tym samym I kwartale 2012 roku w tej grupie bez pracy pozostawało $11 \%$ osób (Bezrobocie rejestrowane... 2012).
} 
W przypadku ludzi młodych, rozpoczynających karierę studencką, czynnik ekonomiczny nie jest jeszcze aż tak istotnym elementem $\mathrm{w}$ podejmowaniu decyzji o wyjeździe do dużego miasta akademickiego, choć na pewno biorą oni pod uwagę potencjalne przyszłe miejsca pracy i zarobki. Ważniejsze na tym etapie rozwoju, który można określić próbnym czasem wchodzenia w dorosłość10, są determinanty o charakterze kulturowym. Do miast przybywa się, by spełniać kulturowy wzorzec „nowego indywidualisty”, który, najlepiej w sposób twórczy, łączy "pracę, zabawę, wypoczynek, potrzeby estetyczne, kulturalne, artystyczne, religijne czy prospołeczne. $\mathrm{W}$ ten typ postaci, członka nowoczesnej klasy średniej, wpisana jest wysoka potrzeba osiągania, czyli pragnienie sukcesu zawodowego i rodzinnego, podwyższone stany empatyczne umożliwiające wczuwanie się $\mathrm{w}$ role nowoczesne i kreatywne". Wymaga to, by formalnemu wykształceniu towarzyszył "bogaty zasób wiedzy podręcznej”, co wiąże się z nieustannym samorozwojem intelektualnym i powiększaniem stanu swojej wiedzy (Jałowiecki, Szczepański 2009: 238-239)11. Aspiracje do tak rozumianej nowej klasy średniej, w przyszłości pewnie metropolitalnej, są jednakowe, niezależnie od pierwotnego kapitału kulturowego. Zgłaszają je nie tylko osoby już zamieszkujące metropolię, ale też te pozostające w bezpośrednim kręgu oddziaływania wielkich miast (mieszkające w stosunkowo niewielkiej odległości geograficznej, uczące się lub pracujące $\mathrm{w}$ nich, decydujące się na codzienne dojazdy - ruchy wahadłowe) i te poznające obowiązujące wzorce powstające $\mathrm{w}$ centrach $\mathrm{w}$ sposób pośredni - dzięki przekazom medialnym i budowanej na ich podstawie świadomości społecznej dotyczącej „właściwych" wzorów, do których należy dążyć12. Miasto staje się „strategicznym obszarem dla pozbawionych kontroli nad własnym życiem aktorów społecznych, ponieważ pozwala im zaistnieć, stać się podmiotami, nawet jeśli nie zyskują bezpośrednio władzy" (Sassen 2007: 3).

${ }^{10}$ Młodzież rozpoczynająca studia w innym mieście pozostaje najczęściej w bardzo ścisłych relacjach z rodziną - jest $\mathrm{w}$ dużej mierze utrzymywana przez rodziców (nawet jeśli coraz większa grupa studentów, i to studiujących w trybie stacjonarnym, jednocześnie wykonuje jakieś prace), jej miejscem stałego zamieszkania jest dom rodzinny, do którego wraca się w weekendy; również związki emocjonalne pozostają w owym okresie cały czas dość silne (por. Wrzesień 2009).

${ }^{11}$ Co interesujące, kiedyś owe umiejętności nieodłącznie wiązały się z wyższym wykształceniem. Zdolność i chęć podejmowania wysiłku intelektualnego były niejako wpisane w sylwetkę człowieka wykształconego. Obecnie naturalna, „nienarzucona” ciekawość poznawcza rzadko kiedy charakteryzuje absolwenta wyższej uczelni (Wrzesień 2009).

$12 \mathrm{O}$ dominującej roli kulturotwórczej centrum mówi globalna koncepcja centrum - półperyferii - peryferii I. Wallersteina, którą z powodzeniem można zaadaptować na potrzeby interpretacji zjawisk zachodzących w skali mikro, w tym przypadku państwa (por.: Wallerstein 2006; Goldfrank 2000). 
Media są jednak nie tylko przekaźnikiem treści kultury masowej i wyznaczników sukcesu. W dyskursie medialnym pojawiła się ostatnimi czasy problematyka migracji młodych ludzi do polskich metropolii. Próbą charakterystyki zjawiska oraz innych $\mathrm{z}$ nim związanych są opublikowane $\mathrm{w}$ roku 2013 w tygodniku „Polityka” artykuły, m.in. Edyty Gietki Wnętrze Stoika13, Wojciecha Markiewicza Sweetaśna muza czy Ewy Wilk Beznadziejni. Głównymi bohaterami tekstu E. Gietki są nowi warszawiacy, czyli osoby, które przyjechały do stolicy z wielu różnych regionów kraju, przede wszystkim w celach zarobkowych. Dlaczego „słoiki” albo „mieszkańcy bez weekendów"? Migranci ci wracają w dni wolne do swoich rodzinnych miejscowości, zwożąc z domu zapasy spożywcze i, jak uważają rodowici mieszkańcy Warszawy, prowincjonalne zwyczaje. Napływowi postrzegani są ${ }^{14}$ jako tańsi konkurenci na rynku pracy, gotowi na wiele upokorzeń (niskie płace, olbrzymie obciążenia obowiązkami zawodowymi, niski standard lokum, trudności w utrzymaniu etc.), byle tylko pozostać w mieście-metropolii (postawa "duit" - do it, czyli robienie wszystkiego, by nie wrócić do miejsca, z którego się wyjechało). Zinternalizowali oni ambicje i dążenia wyróżniające rodowitych warszawiaków - chcą utrzymywać się z satysfakcjonującej pracy, posiadać własne mieszkanie czy dom, korzystać z oferty infrastrukturalnej, kulturalnej i rozrywkowej miasta na równych warunkach. Jak pisze E. Wilk, „pokolenie po pokoleniu - ludzie $\mathrm{z}$ awansu. Z kompleksem niższej wartości, z wyobrażeniem ja idealnego i chroniczną potrzebą potwierdzania swojej wartości zewnętrznymi oznakami" (Wilk 2013: 24).

Nie zawsze jednak przyjezdni chcą się angażować w wysiłek wejścia do klasy miejskiej. „Wolą swojskie disco polo”, przywiezione ze sobą muzyczne gusta i wyobrażenia o zabawie i rozrywce, nie przejmując się zarzutami $\mathrm{o}$ „wieśniackich” upodobaniach. Ciekawy jest fakt, że osoby te nierzadko studiują lub mają wyższe wykształcenie ${ }^{15}$. Trafnie ujął ten sposób myślenia José Ortega y Gasset, który już wiele lat temu stwierdził, że „umysły prze-

${ }^{13}$ Artykuł dotyczy Warszawy, która ma największą moc przyciągania migrantów, ale podobne tendencje, choć z pewnością na mniejszą skalę i z rozmaitym natężeniem, dotyczą wszystkich dużych ośrodków miejskich w Polsce.

${ }^{14}$ Tematyka opisywana $\mathrm{w}$ prasie została szeroko i dogłębnie zbadana na gruncie socjologicznym przez Magdalenę Łukasiuk. W monografii Obcy w mieście. Migracja do wspótczesnej Warszawy autorka analizuje nie tylko biografie migrantów, ale też, choć wyłącznie jako dodatek do badań i ilustrację narastającej wrogości rdzennych mieszkańców stolicy, antagonistyczny dyskurs toczący się w szczególności w przestrzeni Internetu (Łukasiuk 2007: 138-172).

${ }_{15}$ Przywoływany przez W. Markiewicza kulturoznawca Mirosław Pęczak opisuje wydarzenie z olsztyńskich juwenaliów, gdy w celu pastiszu zaproszono na zabawę studencką grupy wykonujące disco polo. Zabieg był w zamyśle żartem $\mathrm{z}$ tego typu muzyki, a okazał się sukcesem. Jak mówi Pęczak: „studenci - w części słoikowcy i duici - gdy sobie popili piwa, stracili dystans do konwencji i świetnie się bawili". 
ciętne i banalne, wiedząc o swej przeciętności i banalności, mają czelność domagać się prawa do bycia przeciętnymi i banalnymi i do narzucania tych cech wszystkim innym" (Ortega y Gasset 2002: 16).

Problematyka migracji do miast, oznaczającej chęć poprawy własnego losu w różnych sferach życia, nie jest oczywiście żadnym novum (por.: Pohoski 1963; Wewnętrzne migracje... 1979; Stasiak (red.) 1990). Nowe nie są też procesy stygmatyzowania przyjezdnych jako ludzi gorszej kategorii ani obawy przed ruralizacją, czyli następstwami „ruchu społecznego mieszkańców wsi do miast z zamiarem uzyskania awansu społecznego przy jednoczesnym zachowaniu dotychczasowej tożsamości kulturowej" (Sadowski 1994: 15)16. Nowością nie jest też nawet to, że do miasta - centrum akademickiego nie przyjeżdża się de facto $\mathrm{w}$ celu zdobycia dyplomu wyższej uczelni - przykładowo, w badaniach prowadzonych przez Andrzeja Sadowskiego w 1994 roku wyższe wykształcenie zajmowało przedostatnie miejsce w hierarchii wartości ludności miast Polski północno-wschodniej - i to zarówno rdzennej, jak i napływowej (Sadowski 1994: 175-183). Dziś jednakże możemy obserwować zasygnalizowany wcześniej fenomen, który na potrzeby artykułu określiłam jako wczesną migrację.

W zjawisku wczesnej migracji ujawniają się dwie tendencje: jedną $\mathrm{z}$ nich jest chęć awansu poprzez "zaczepienie się", trwałe "zainstalowanie się" w mieście już we wczesnej dorosłości, drugą zaś postępująca instrumentalizacja wykształcenia. Studia nie są celem jedynym i autotelicznym. W powszechnym mniemaniu kształcenie na uczelniach wyższych powinno być $\mathrm{w}$ istocie przygotowaniem do pracy zawodowej. Za niepowodzenia absolwentów na rynku pracy obarcza się winą niedostosowane do wymagań współczesnej gospodarki programy studiów, niechęć młodzieży do kierunków ścisłych, zbyt teoretyczne zajęcia bez możliwości praktycznego zastosowania etc. Studia akademickie uważa się za efektywne, gdy po ich ukończeniu absolwent znajduje pracę zgodną ze swoim wykształceniem. Kierunki nieprzygotowujące do żadnego specyficznego zawodu, czyli głównie szeroko

16 Warto też $\mathrm{w}$ odniesieniu do migrantów przywołać wprowadzony przez Roberta K. Mertona termin "ludzie marginesu”, określający osoby pozostające pod wpływem dwóch grup nacisku: o wysokim i niskim statusie, w których bądź są intruzami, bądź są uznawane za nielojalne. $Z$ jednej strony brakuje im kompetencji kulturowych (lub brak ten jest przypisywany stereotypowo), aby stać się pełnoprawnymi członkami klasy miejskiej, z drugiej - w środowiskach pochodzenia są tymi, którzy już nie pasują, którzy się wywyższają, którzy uciekli, bo nie czuli się dobrze "u siebie” (zob. wywiad z Tomaszem Sadowskim, prowadzącym blog „Warszawskie Słoiki. Portal warszawiaków prowincjonalnych” (www.sloiki.waw.pl), http:// warszawa.gazeta.pl/warszawa/ 1,34889,13585565,_Naczelny_Sloj_ stolicy_Sloiki_to_elita_ Ludzie_mobilni.html?as=1 [19.04.2013]. Wywiad rozpoczyna cykl portalu Gazeta.pl zatytułowany „My, warszawiacy 2013” 26.03.2013). 
pojęte humanistyczne i społeczne, są uważane albo za niepotrzebne, albo wręcz za nierentowne. Dlatego też podlegają nieustannym zmianom, by lepiej wpisać się $\mathrm{w}$ oczekiwania zarówno studentów, jak i potencjalnych pracodawców, którzy to w dużej mierze są odpowiedzialni za deprecjonowanie treści i sposobów nauczania na polskich uczelniach, przenosząc swoje oczekiwania wobec kwalifikacji przyszłych pracowników właśnie na szkoły wyższe. Pracodawcy bardzo krytycznie wypowiadają się o dzisiejszych kandydatach na pracowników posiadających wyższe wykształcenie, zarzucając im brak umiejętności przydatnych w wykonywaniu określonej pracy, za co winę ponosi, ich zdaniem, przestarzały system szkolnictwa oderwany od realiów współczesnej gospodarki. Niezadowolenie decydentów na rynku pracy skutkuje podejmowaniem konkretnych kroków przez władze szkolnictwa wyższego na szczeblu centralnym i w konkretnych jednostkach, co ma doprowadzić do wzrostu zatrudnienia, a pośrednio także do większej innowacyjności i konkurencyjności polskiej gospodarki. Programy studiów układa się pod kątem możliwości nabycia umiejętności przydatnych i cenionych na rynku pracy, postępuje specjalizacja kierunków, w MNiSW zwołuje się obrady $\mathrm{z}$ ludźmi biznesu $\mathrm{w}$ odpowiedzi na apele środowiska pracodawców o dramatycznie słabej jakości absolwentów ${ }^{17}$. Punkt ciężkości wyraźnie przesuwa się w stronę instrumentalnego traktowania kształcenia akademickiego.

Młodzi ludzie ulegają takiemu sposobowi myślenia. Zdają sobie sprawę, że ich kariera zawodowa w obecnych warunkach zależy w coraz większym stopniu od wcześniejszego doświadczenia i wyspecjalizowania, dlatego już studenci poszukują pracy, często w pełnym wymiarze godzin, a tę zdecydowanie łatwiej, mimo dużego bezrobocia w skali kraju, znaleźć w dużym mieście. Nie oznacza to, że studenci sami się utrzymują, choć i takie przypadki bywają. Natomiast z pewnością poprzez pracę stają się jeszcze bardziej związani z miastem. Decyzja o rozpoczęciu studiów w dużym mieście to obecnie już nie tylko wyjazd w celu edukacyjnym, to decyzja o migracji i początek walki o awans społeczny, którego dziś nie zapewnia samo zdobycie dyplomu, ale przynależność do klasy miejskiej już tak. Nie dziwi zatem, że $\mathrm{w}$ dobie kulturowego przymusu przynależności do grup $\mathrm{w}$ wielu aspektach wygranych, a taką są mimo wszystkich zastrzeżeń właśnie miejskie klasy średnie, młodzi Polacy poszukują swojej drogi do sukcesu i podążają do choćby i rodzimych metropolii - za dyplomem i szansami, których być może nigdzie indziej nie ma.

17 Spotkanie pod hasłem „Biznes dla uczelni, uczelnie dla biznesu” odbyło się w maju 2012 roku; wzięło w nim udział prawie 90 osób ze świata nauki i biznesu (zob. http:// www.pi.gov.pl/PARP/chapter_86197.asp?soid=0786034B35F44A61AD06A39DA963E7F1 [dostęp: 19.08.2014]. 


\section{BIBLIOGRAFIA}

Bajerski A. (2009), Przeksztatcenia struktury przestrzennej szkolnictwa wyższego w Polsce po 1989 r., Bogucki Wydawnictwo Naukowe, Poznań.

Bezrobocie rejestrowane I kwartat 2012 r., Informacje i opracowania statystyczne (2012), GUS, Warszawa.

Bieńkowska D., Ulasiński C., Szymańska J., red. (2010), Trajektorie migracyjne województwa podkarpackiego - raport z badania studentów, projekt realizowany przez Centrum Doradztwa Strategicznego, Kraków, http://www.cds.krakow.pl/zalaczniki/158/rap ort\%20studenci\%20-\%20wersja\%20ostateczna\%20cz.\%20b.pdf [19.04.2013].

Bromberek B. (1988), Młodzież studencka. Jej kształcenie i koncepcje życia, PWN, Warszawa-Łódź.

Drozdowicz Z., Iwaszkiewicz M., red. (2008), Bariery rozwoju polskich uczelni, „Człowiek i Społeczeństwo" nr XXVIII, Wydawnictwo Naukowe UAM, Poznań.

Gietka E. (2013), Wnętrze Stoika, „Polityka” nr 13 (2901).

Goldfrank W.L. (2000), Paradygmat odzyskany? System-świat I. Wallersteina i jego analiza, http://www.turowski.uni.wroc.pl/paradygmat.htm [dostęp: 19.04.2013].

Herbst M. (2012), Edukacja jako czynnik $i$ wynik rozwoju regionalnego, Wydawnictwo Naukowe Scholar, Warszawa.

Iglicka K. (2010), Powroty Polaków po 2004 roku. W pętli pułapki migracji, Wydawnictwo Naukowe Scholar, Warszawa.

Jałowiecki B., Szczepański M.S. (2009), Miasto i przestrzeń w perspektywie socjologicznej, Wydawnictwo Naukowe Scholar, Warszawa.

Jankowska M., Krasoń J. (2009), Hierarchia wartości i sposoby ich realizacji. Młodzi bydgoszczanie wobec wartości, Oficyna Wydawnicza Impuls, Kraków.

Kaczmarczyk P. (2012), Labour Market Impacts of Post-accession Migration from Poland, [w:] OECD. Free Movement of Workers and Labour Market Adjustment. Recent Experiences from OECD Countries and the European Union, OECD, Paris.

Kołodko G.W. (2008), Wędrujący świat, Prószyński i S-ka, Warszawa.

Łukasiuk M. (2007), Obcy w mieście. Migracje do wspótczesnej Warszawy, Wydawnictwo Akademickie Żak, Warszawa.

Markiewicz W. (2013), Sweetaśna muza, „Polityka” nr 15 (2903).

Micińska M. (2008), Dzieje inteligencji polskiej od odzyskania niepodległości w 1918, [w:] Inteligencja w Polsce. Specjaliści, twórcy, klerkowie, klasa średnia?, red. H. Domański, Wydawnictwo IFiS PAN, Warszawa.

Migracje wewnętrzne ludności 2002, wyniki Narodowego Spisu Powszechnego Ludności i Mieszkań z 20 maja 2002 (2003), GUS, Warszawa.

Morasko: nowoczesny kampus czy "getto za torami"?, "Gazeta Wyborcza Poznań", 15.04.2013, http://poznan.gazeta.pl/poznan/1,36037,13738305,Morasko_nowoczesny_kampus_ czy_getto_za_torami_.html [dostęp: 19.04.2013].

Nowak S., red. (1991), Studenci Warszawy. Studium dtugofalowych przemian postaw $i$ wartości, Wydawnictwa Uniwersytetu Warszawskiego, Warszawa.

Okólski M. (2011), Modernizacyjna rola migracji, [w:] Ekonomia, kultura, polityka, społeczeństwo, red. W. Morawski, Wydawnictwa Akademickie i Profesjonalne, Warszawa.

Ortega y Gasset J. (2002), Bunt mas, Wydawnictwo Muza, Warszawa.

Pachociński R., Kierunki reform szkolnictwa wyższego na świecie, Instytut Badań Edukacyjnych, Warszawa 2004. 
Pohoski M. (1963), Migracje ze wsi do miast: studium wychodźstwa w latach 1945-1957 oparte na wynikach ankiety Instytutu Ekonomiki Rolnej, PWE, Warszawa.

Potulicka E., Rutkowiak J. (2010), Neoliberalne uwikłania edukacji, Oficyna Wydawnicza Impuls, Kraków.

Sadowski A. (1994), Procesy ruralizacji. Ludność wiejska w mieście, Wydawnictwo Uniwersytetu Jagiellońskiego, Kraków.

Sassen S. (2007), Globalizacja. Eseje o nowej mobilności ludzi i pieniędzy, Wydawnictwo Uniwersytetu Jagiellońskiego, Kraków.

Stasiak A., red. (1990), Migracje ze wsi do miast ze szczególnym uwzględnieniem lat 1979-1985, PWE, Warszawa.

Szkoty wyższe $i$ ich finanse w 2010 r. (2011), GUS, Warszawa.

Wallerstein I. (2006), Nowoczesny system-świat, [w:] Wspótczesne teorie socjologiczne, red. A. Jasińska-Kania, L. Nijakowski, J. Szacki, M. Ziółkowski, Wydawnictwo Naukowe Scholar, Warszawa.

Wewnętrzne migracje ludności do miast i aglomeracji miejskich (1979), oprac. T. Stpiczyński, GUS, Warszawa.

Wilk E. (2013), Beznadziejni, „Polityka” nr 16 (2904).

Wrzesień W. (2009), Europejscy poszukiwacze. Impresje na temat wspótczesnego pokolenia polskiej młodzieży, PWN, Warszawa. 